\title{
US report accuses NSF of polluting polar environment
}

\section{Washington}

US ANTARCTIC research bases run by the National Science Foundation (NSF) are polluting the unspoilt polar environment in defiance of national and international regulations, according to a report released last week by the Washington-based Environmental Defense Fund. But NSF officials say that "increasing and extensive efforts to improve perfomance" have been under way since the late 1970 s and the situation is nothing like as bad as the report claims.

Bruce Manheim, the report's author, says that McMurdo Sound where the largest US base in Antarctica is located is more heavily polluted than virtually any part of the United States' own coastal waters. Polychlorinated biphenyls (PCBs) and heavy metals - including lead and cadmium - are now found in the tissues of Antarctic penguins and seals.

Manheim describes it as "ironic" that the pristine conditions that make much Antarctic research possible are being harmed by the day-to-day running of research bases. According to the report, raw sewage is discharged into the sea, combustible wastes are burnt without emission controls, non-combustible wastes are often dumped into the sea and the air is polluted by diesel-powered generators.

"Other nations are doing a better job than the United States", says Manheim. Australia removes all wastes from the Antarctic; Poland uses a filtered sewage sytem and both New Zealand and Australia control incinerator emissions. Britain's practices are said to be the same as those of the United States.

Jack Talmadge, director of polar coordination and information at NSF, describes the claims of large-scale pollution in McMurdo Sound as "preposterous".

Some of the criticisms in the report are out of date, he says. Others "may be legitimate" but do not mean that the United States does not care about the Antarctic environment. NSF has taken informal advice from Australia which Talmadge describes as the "leader" in minimizing Antarctic pollution and is looking for funds to help clean up the McMurdo base.

The report also claims that NSF has misled the public and Congress. In 1978, Congress enacted the Antarctic Conservation Act which gave NSF responsibility for promulgating regulation to prevent pollution, but NSF has never gone beyond issuing guidelines. The act also directed NSF to protect all Antarctic marine life. But the report says that activities that may affect marine life are not closely regulated.

The report points out that the number of bases in Antarctica is likely to grow as more nations seek to "conduct substantial scientific research activity" so that they become eligible to accede to the Antarctic Treaty as consultative partners. That status is necessary for a say in what happens to Antarctica and its resources. The first steps to open Antarctica to mining

were taken at this year's treaty meeting (see Nature 333, 588; 1988).

Exploitation of Antarctica's mineral resources is still a long way off, however. A more pressing problem is the growth of tourism. Talmadge says that next season he expects 3,200 ship-borne tourists to visit the Antarctic Peninsula, where most bases are located. The total number of scientists there is probably less than 500. And, unlike scientific activities, tourism is almost totally unregulated.

Alun Anderson

\section{UK space community cheered by contribution to solar research}

\section{London}

BRITAIN's space science community is cheered this week by the size of the country's contribution to the $\mathrm{SOHO}$ and CLUSTER missions. This eight-year programme is the first major step in the European Space Agency's (ESA) 20-year programme Horizon 2000. Britain is to spend $£ 56$ million on the satellites and $£ 20$ million on instruments. Announcing Britain's contribution, Arthur Pryor, head of the British National Space Centre said it was "an exciting and challenging opportunity for the whole science community," This solar-terrestrial science project will cost about $£ 750$ million; just over half the cost is being met by ESA and the rest by NASA (National Aeronautics and Space Administration).

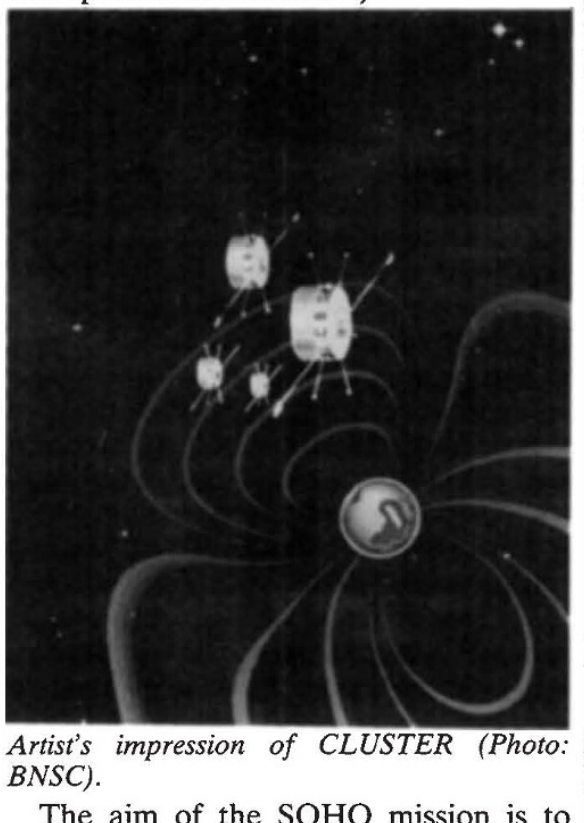

The aim of the SOHO mission is to understand the nature of the Sun's atmosphere and how it is heated, to study how the Sun expels material into space and to probe the Sun's interior by studying its vibration patterns. CLUSTER, which will consist of four identical spacecraft flying in close formation in Earth orbit, will study the Earth's magnetosphere and the solar wind. Both missions will be launched in 1995 and should be able to provide useful data four months after launch. CLUSTER will be complemented by two NASA spacecraft (WIND and POLAR) and a joint US-Japan satellite (GEOTAIL), which will explore other parts of the magnetosphere.

Britain surprised its partners in Europe when it agreed to provide the $£ 20$ million to support the British instruments which were selected for the missions. In the European space community, Britain made itself unpopular by its refusal to consent to a five per cent annual increase in the ESA budget beyond 1989. But a condition of the country's involvement in the Columbus space station programme was that it would reconsider that veto, and it has until the end of the year to do so.

Christine McGourty

\section{New data centre}

\section{Washington}

THE US National Science Foundation (NSF) agreed on 18 August to provide \$5.5 million over five years for a new National Center for Geographic Information and Analysis. Its aim will be to develop more powerful methods of dealing with the explosion of data from such sources as remote-sensing satellites. It is to be run by a consortium of the University of California at Santa Barbara, the University of Maine at Orono and the State University of New York at Buffalo.

Alun Anderson

\section{European genome plan London}

THE European Commission is undertaking a £20 million research project to sequence the human genome. The commission will provide half of the funds; the rest will be contributed at a national level. The project, 'Predictive Medicine', must still be approved by the Council of Ministers and the European Parliament. The 3-year project starts in 1989. 